\title{
Art Rock: Definition of the Term with Regard to the Development of Czech Designating Practice
}

\author{
Jan Blüml
}

The problem of designating, defining and hierarchization of style-genre categories of modern popular music is fairly complex. The situation is made still more complicated especially by the ambiguity of the terms, due to the variety of interpretation of the terms in various historical periods, as well as the different understanding of the terms within a particular phase of history. Although the immense size of modern popular music makes it impossible to register all semantic modifications and all terminological deviations, with the passing of time it is relatively possible to describe at least the major semantic variants, as they became fixed in the wider social consciousness.

In the following text I will approach the term "art rock" from the aspect of the problems outlined above. First I will deal with the domestic and foreign development of the term and then with the issues of related terms, synonymous expressions, and alternative terms. Beside the description of an important style-genre category of rock music I will explain the general problems involved in the designating practice in modern popular music.

Many terms designating style-genre areas in modern popular music have been coined. Many of them also became extinct. Some stood the test of time by having their meaning changed significantly, others become stable and no longer undergo a major modification of meaning and change in the collective consciousness so that sooner or later they enter the written history of music. However, not even this may guarantee that later a term will reappear, with an altered meaning or in completely new circumstances. The latter possibility also affects the term "art rock".

This term appeared first in music journalism in the first half of the 1970s. The attribute "art" in art rock was to imply that it was not the mainstream rock, the songs of which do not go beyond the standard three-minute format and only meet the role of entertainment, but that it is a kind of music which tries to be an art in the true sense of the word, an art aesthetically comparable with the music of the masters of classical music. 
To this goal also corresponded the choice of the means of expression and composition, the instrumental virtuosity, etc.

In 1976, in a collective volume of papers, The Rolling Stone Illustrated History of Rock \& Roll, the first extensive paper on art rock was published. The author was a music publicist and cultural historian, John Rockwell. He understands by the term art rock a wide variety of manifestations of music, their common feature being inspiration by classical music. $\mathrm{He}$ also interprets it as integration of means of expression from other styles of modern popular music, for instance jazz or folk. Art rock, Rockwell says, is a distinct trend of the rock of the 1970s. In the beginning there was the Beatles record Sgt. Pepper's Lonely Hearts Club Band (1967). The author's term art rock covers several lines of development of rock music in the 1970s. He calls one of them "eclectic art rock". Into this category he puts the music of British groups Genesis, King Crimson, Electric Light Orchestra, Queen, Supertramp, Sparks, 10cc, Gentle Giant and Be-Bop Deluxe; the Dutch group Focus, and the American groups Kansas, Styx a Boston. The main representative of the "eclectic art rock", the author believes, is the work of the British group Roxy Music between 1971 and 1973. The shared means of expression in the music of these groups are, according to Rockwell, the structural and semantic changes within each composition; in particular the change in tempo, degree of loudness, style, general mood, etc. Another area of art rock of the 1970s is seen by Rockwell in the rock avant-garde, which starts for instance with the record Two Virgins by John Lennon and Yoko Ono (1969). He calls Brian Eno and Robert Fripp the major representatives of London rock avant-garde. From New York he mentions John Cale, La Monte Young, Terry Riley and a few more. Another form of art rock is found by Rockwell in the music of the groups which in the seventies developed the acid rock of the psychedelic era covering the second half of the sixties. Here the author writes about music of the group Pink Floyd, especially about their record of 1973, The Dark Side of the Moon. Next he discusses the projects of the group of Frank Zappa, Mothers of Invention. The last area of art rock, discussed by Rockwell in his paper, is the post-psychedelic rock of the West German groups Kraftwerk or Tangerine Dream, which partly developed the music of Karlheinz Stockhausen, György Ligeti, Iannis Xenakis, and other avant-garde composers of postwar art music in Europe. ${ }^{1}$

The term art rock soon found its way into major encyclopedic publications. One of the first references is found in the third, updated edition of Lillian Roxon's Rock Encyclopedia (1977). Although it contains several entries on lesser style-genre types, such as the baroque rock, or the later spheres of rock, for instance the new wave, there is no separate entry Art Rock. Maybe the incriminated term was not given an entry because of its semantic ambiguity in those days. A note on art rock is found in the entry King Crimson. Its author points out the beginning of the group - "the art-rock period of 1967-1972". ${ }^{2}$

$1 \quad$ John Rockwell, “Art Rock“, in: Jim Miller (ed.), The Rolling Stone Illustrated History of Rock \& Roll (New York, 1976), p. 347-352.

2 “King Crimson”, in: Ed Naha and Lillian Roxon (eds.), Lillian Roxon's Rock Encyclopedia (New York, 1978), col. 291. 
In Czechoslovakia, the term art rock was used for the first time in 1979 in an article by Jiří Černý, on the music group Yes, headlined Má art-rock budoucnost? Yes [Is There a Future for Art-Rock? Yes]. The way this term was at that time understood is shown by a quotation from that article: "The fact that Sgt. Pepper, the $8^{\text {th }}$ album of the Beatles from 1967, is thought to be the first great model and stimulus for the boldest experiments in pop music, is not always flattering only. Art-rock, classical rock, orchestral rock - all these are found in encyclopedias, whose authors believe that they guard the true, that is the rebelling face of rock music, expressions implying superiority, pomposity, excessive complications, keeping an eye on being acknowledged by snobs, artificiality, non-originality, etc."3

The negative connotations associated with the term art rock were by no means a Czech privilege only. Music snobbery and artificiality hiding under the name art rock was commented upon in 1983 by the American author Charles Brown. In his book The Art of Rock and Roll the term art rock was loosely defined as rock music with generally higher artistic ambition than the mainstream rock and which in some ways processed classical music from Europe as well as from outside Europe, such as India. In this connection Brown mentions the music of groups Moody Blues, Procol Harum, Kinks, Who, Nice, Emerson, Lake and Palmer, Genesis, King Crimson, Yes, Renaissance and Roxy Music. ${ }^{4}$

In the first edition of the general encyclopedia of music, The New Grove of Music and Musicians (1980), the entry Art Rock is missing; absent is even a separate treatment of rock as such. The history of rock music is found in a wider entry, Popular Music, where in the description of the development of rock in the seventies is a brief mention of art rock. The author of the entry, Charles Hamm, writes that the groups King Crimson and Tangerine Dream were later representatives of the style which was called art rock. ${ }^{5}$

A longer text on art rock is found in the book Rock of Ages (1986), by Ken Tucker. He regards art rock, together with hard rock and heavy metal, as a musical opposition to the more chamberlike rock stream of the seventies, called singer-songwriters. He claims that the main features of art rock are higher aesthetic demands and the effort to be accepted by the circles of art music. He believes that an important prerequisite of the origin of art rock was the arrival of a generation of musicians educated in classical music, who were familiar with the repertoire of art music and who, like many others, were charmed by the music of the Beatles. As representatives of the art rock style, Tucker enumerates the music groups Emerson, Lake and Palmer, Jethro Tull, Yes, Rush, Uriah Heep and Genesis. A special position in art rock is taken, he believes, by Pink Floyd, whose music was not based on

3 Jiři Černý, "Má art-rock budoucnost? Yes" [Has Art-Rock the Future? Yes], Melodie [Melody], 17 (1979), No. 5, p. 148-149.

4 Charles T. Brown, The Art of Rock and Roll (Englewood Cliffs, N. J., 1983), p. 179-192.

5 Charles Hamm, "Popular Music", in: Stanley Sadie (ed.), The New Grove Dictionary of Music and Musicians, vol. 15 (London, 1980), col. 120. 
instrumental virtuosity. In connection with art rock, Tucker mentions another group, Led Zeppelin, which combined art rock elements with hard rock and heavy metal. ${ }^{6}$

In 1986 was also published a revised edition of an older encyclopedia, The Harvard Dictionary of Music, under the title The New Harvard Dictionary of Music, which for the first time contained entries on modern popular music. There is a short entry, Art Rock. Its author, Patrick T. Will, defined art rock as a style of rock music, which is distinguished by extensive musical forms and more complex harmonies, untypical for the majority of modern popular music. Will also writes that some art rock groups work with the original material of classical music - as an example he gives the adaptation of the composition by Modest Petrovich Mussorgsky, Pictures from an Exhibition, by the group Emerson, Lake and Palmer -, while other groups used more general composition procedures and principles of classical music. In this connection he mentions the application of the sonata form in the composition Close to the Edge by the group Yes. ${ }^{7}$

During the seventies, in Czechoslovakia the term art rock was not current enough yet to be given a separate entry in the subject section of the Encyklopedie jazzu a moderni populární hudby [The Encyclopedia of Jazz and Modern Popular Music], first published in 1980 and in updated form in $1983 .^{8}$ There is no reference to the style-genre type in the wider entry Rock either, whose author was Lubomír Dorůžka. In the nominal section of the encyclopedia published in 1986 a 1987 and which describes the world scene, the term art rock occurs already in four entries: Avtograf, Genesis, King Crimson and Yes. Vladimír Fejertag, the author of the entry Avtograf, regards art rock as a category equivalent to hard rock style, when he writes: "On the repertoire of the group, art rock and hard rock prevail [...]". Jiří Černý in his article on the group Genesis says: "Like the groups Emerson, Lake and Palmer, King Crimson, Pink Floyd and Yes, Genesis is one of the British groups which grew from the R \& R roots to a music now called art rock [...]". Petr Dorůžka when discussing the group King Crimson confirms the existence of the art rock wave: "[...] developing the European tradition, the group (King Crimson) was the precursor of the art-rock wave (v. Yes, Genesis)." Petr Poledñák, the author of the entry on the group Yes, thinks likewise: "The group Yes was one of the most progressive

6 Ed Ward, Geoffrey Stokes and Ken Tucker, Rock of Ages: The Rolling Stone History of Rock and Roll (New York, 1986), p. 480-486.

7 Patrick T. Will, “Art Rock”, in: Don Michael Randel (ed.), The New Harvard Dictionary of Music (Cambridge, 1986), col. 56.

8 The manuscript of the first volume of the encyclopedia, published in 1980, was finished and handed over to the Supraphon publishing house already in the early autumn of 1975. Since the term art rock began to appear in Czech magazines and books only in the second half of the seventies, it is naturally missing in volume I. The text of the revised and enlarged edition of the subject section of the encyclopedia was finished prior to 1982 and published in 1983. The absence of the term art rock from the new entries is due to the fact that in those days it was little known in this country, or was found ambiguous. It should also be noted that the extent of the Appendix to the second edition of volume I of the encyclopedia was limited. The authors say in the preface "it had to be confined to the barest necessary data and assessments". 
achievements of the British art rock [...]". ${ }^{9}$ In the Czechoslovakia section in the 1990 encyclopedia, the term art rock appears more often. Reference to it is found in the entries Abraxas, Barel-rock, Extempore, Index Y, Modrý Efekt, Michal Pavlíček, Pražský Výběr, Michal Prokop, Synkopy and Oldřich Veselý.

The first Czech attempt at a definition of the term art rock is found in the encyclopedic dictionary by Josef Vlček, Rockové směry a styly [Rock Streams and Styles] (1988). The term art rock is explained thus: "Art rock. One of the most ambiguous terms in rock music. By it, it is understood: 1. All streams of rock music with the ambitious goal of creating primarily a work of art and the from it ensuing tendency to put artistic value above commercial value. 2. The stream of multimedial rock, 'synthetic art' (e.g. videopop, stage rock, various combinations with ballet, fusion with theatre, etc.). The two meanings are often interconnected. In each period, however, something else is meant by this term. As art rock was called glitter, the music of groups like Yes and Genesis, punk, etc." 10

In his previous large encyclopedia of 1982-1984, the three-volume Rock: 2000, Vlček did not use the term art rock. Many music groups which now would be ranked with art rock, he calls pomp rock.

In 1990 was published the first edition of the university textbook Rock Music Styles. The American author Katherine Charlton discusses even lesser streams and styles in the history of rock. One chapter deals with the style-genre type of art rock. Charlton believes that this mainly British phenomenon, art rock, was an outcome of the increased interest in thematic and conceptual albums in the late sixties as well as the result of launching a new radio format, FM, which in those days concentrated on broadcasting longer rock compositions. By art rock the author understands three interlocked types of rock music. The first, simplest form was the rock which used music instruments of a symphonic orchestra. The outcome of this stream was the work of producers Phil Spector and George Martin in the sixties. In connection with this type of art rock, Charlton mentions the group Moody Blues, one of the first to cooperate with a symphonic orchestra and fairly often using a musical instrument called mellotron. Here the author reminds the readers of the groups Genesis, Procol Harum, Jethro Tull and Electric Light Orchestra. The second category of art rock was the groups, whose members were musicians with classical training, whose compositions in length and complexity approached larger forms of classical music. They included the groups Yes and King Crimson. In this second art rock category were also the groups which developed existing compositions of classical music, such Emerson, Lake and Palmer. The third type of art rock in Charlton's classification is represented by groups inspired by some streams of art music of the $20^{\text {th }}$ century, in

\footnotetext{
9 “Avtograf”, "Genesis”, “King Crimson”, in: Antonín Matzner, Ivan Poledňák and Igor Wasserberger (eds.), Encyklopedie jazzu a moderní populární hudby: Část jmenná - světová scéna, $A-K$ [The Encyclopedia of Jazz and Modern Popular Music: Nominal Part - World Stage, A-K] (Prague, 1986); "Yes", in: Antonín Matzner, Ivan Poledňák and Igor Wasserberger (eds.), Encyklopedie jazzu a moderní populární hudby: část jmenná - světová scéna, $L-Z ̌$ [The Encyclopedia of Jazz and Modern Popular Music: Nominal Part - World Stage, L-Ž] (Prague, 1987).

Josef Vlček, Rockové směry a styly (Prague, 1988), p. 10.
} 
particular electro-acoustic music and minimalism, such as Pink Floyd; then the compositions by Frank Zappa and his group Mothers of Invention, Laurie Anderson and the West German group Kraftwerk. ${ }^{11}$

In 1993, art rock was loosely defined by the musicologist Allan F. Moore as an artistically ambitious area of rock music of the seventies, in the composition of which had a share, musicians with a classical education, such as Rick Wakeman or Kerry Minnear. ${ }^{12}$

The second edition of the encyclopedia The New Grove of Music and Musicians (2002) already has a separate entry Art Rock. Its author Robert Walser gives three options for the interpretation of the term: 1 . Art rock is a style inspired by European classical music, which goes beyond the expression of traditional rock by exceptional instrumental ability or fuses with other styles. This is found in the records Sgt. Pepper's Lonely Hearts Club Band of the group Beatles and Days of Future Passed from the group Moody Blues in 1967. The main representatives, however, are the British groups Nice, Emerson, Lake and Palmer, Deep Purple, Yes, Procol Harum, Pink Floyd, Genesis, King Crimson, Jethro Tull and their work in the seventies. From American groups the author mentions Styx, Kansas and Boston. 2. In a wider sense of the word, art rock also means the music of groups and soloists, such as Roxy Music, Brian Eno, Frank Zappa, David Bowie, Velvet Underground, Steely Dan, Rush, and Laurie Anderson. Walser reminds the readers that the common denominator of the work of the two categories of rock groups and musicians is the integration of elements of art music. The distinguishing criterion is primarily the approach to one's own work; whether it is "serious art" of the groups such as Yes, or the irony and self-irony of musicians such as Frank Zappa. 3. The term art rock can also designate some streams of the heavy metal of the eighties, which to some degree were also influenced by classical music..$^{13}$

In recent years in both Czech and foreign popular literature the term art rock has become increasingly popular in connection with the later and not yet quite profiled stylegenre streams of rock music, which belong to indie rock. It is a fairly wide spectrum of various kinds of music inspired by glam rock, new wave, punk, post-punk, and many other rock streams. ${ }^{14}$

From what was said above it follows that the term art rock from the first half of the seventies, when it for the first time appeared in Anglo-American music literature, was used to designate several specific areas of rock music. An analysis of the accessible recent literature reveals that now this term in the USA and in Britain most often means: 1. Type of music represented by the recordings of the groups Yes and Genesis especially from the

$11 \quad$ Katherine Charlton, Rock Music Styles: A History (Boston, 1990), p. 217-229.

12 Allan F. Moore, Rock: The Primary Text: Developing a Musicology of Rock (Buckingham, 1993), p. $90-98$.

13 Robert Walser, “Art Rock”, in: Stanley Sadie and John Tyrell (eds.), The New Grove Dictionary of Music and Musicians, vol. 1 (New York, 2002), col. 93.

14 See for instance "Art Rock", in: Wikipedia: The Free Encyclopedia [online], available at www: <http:// en.wikipedia.org/wiki/Art_rock>. 
first half of the seventies; 2 . The style-genre type of rock of the seventies, generally known glam rock or glitter rock, with the group Roxy Music and the singer David Bowie as its main representatives. In Czechoslovakia the term art rock mostly occurs in the first sense.

In general it holds that in contemporary communication about music the term art rock can function on several interconnected levels of meaning. It can mean:

1. The general creative and aesthetic principle. In this sense art rock may be include: a) the rock which by its own or by borrowed means achieves a higher aesthetic and artistic levels; b) the rock which makes use of specific means of expression found in other areas of art, for instance in classical music, fine arts, literature, etc.; c) the rock based on instrumental virtuosity and a complex composition and structure.

2. Specific style-genre area of rock music. In this sense the term art rock functions minimally on two hierarchical levels: a) art rock as a superior category, which includes the relatively wide spectrum of the rock of various historical periods and which to some degree can be understood as an opposition to the rock mainstream; b) art rock is the specific style-genre type of the rock of the seventies, represented for example by the groups Yes or Genesis.

Communication on art rock as a specific style-genre type of rock music is now complicated in particular by the fact that in both above meanings it is confused with the term progressive rock, in short prog rock or in the Czech equivalent, progresivní rock [progressive rock]. So it is a term which entered the terminology of popular music in the second half of the sixties. In those days, the English underground radio stations thus called the new streams of psychedelic music, different from the rock mainstream, and thought by listeners as being fairly experimental. At the end of the sixties, the music publicist Petr Dorůžka wrote this about the term progressive rock: "it could mean anything: in no case, however, was it a style of music, only a creative approach [...]". ${ }^{15}$ After 1970 the term was defined more closely and became stable. At the time progressive rock was a wider style-genre area, characterized by the crossing of the boundaries of mainstream rock by integrating elements of classical music, modern jazz, and other musical as well as non-musical streams of art.

Now the terms art rock and progressive rock are often found synonymous. According to the tradition of this or that communication network they jointly designate a fairly wide area of an artistically ambitious rock or, reversely, tend to designate a particular the style-genre type of the seventies. On the conception of art rock and progressive rock as synonyms are based or admit it for example Princeton University's Wordnet Dictionary, Encyclopaedia Britannica, Guide to the Progressive Rock Genres, Progbibliography.de, The New Harvard Dictionary of Music, and the authors Edward Macan, John Covach, Nors S. Josephson and Bill Martin. ${ }^{16}$

15 Petr Dorůžka, "Po stopách progresivního rocku" [Following the Footsteps of Progressive Rock], in: Petr Dorůžka (ed.), Hudba na pomezí [Music on the Border] (Prague, 1991), p. 17.

16 “Art Rock", in: Princeton University's Wordnet dictionary [online], available at www: <http://wordnet. princeton.edu/>; “Art Rock", in: Encyclopaedia Britannica [online], available at www: <http://www. britannica.com/>; Guide to the Progressive Rock Genres [online], available at www: <http://www.gepr. 
The terms art rock and progressive rock are often also interpreted as hierarchically differentiated categories. Some authors claim that art rock is a relatively wider, historically not yet closed circle of artistically ambitious rock, part of which is the style-genre type of the seventies, the progressive rock, represented by the groups Yes or Genesis. Other sources give the reverse - progressive rock is a superior category, which in addition to other style-genre types includes art rock.

The first option in the interpretation of the term art rock is offered for example by Brian Robinson in Somebody Is Digging My Bones. The author says that progressive rock is part of a wider category, art rock. As typical examples of art rock outside the category of progressive rock he gives the music of the groups or soloists Captain Beefheart, David Bowie, Brian Eno, Kraftwerk, Mike Oldfield, Talking Heads, Tangerine Dream, Vangelis and Frank Zappa. ${ }^{17}$ The authors of the encyclopedia The New Rolling Stone Encyclopedia of Rock \& Roll also take art rock as a wider term, which includes both progressive rock and glam rock. ${ }^{18}$ The same approach is found in the dissertation by Bernward Halbscheffel and a similar interpretation occurs in the entries Art Rock in electronic databases of The Oxford Companion to Music and Grove Music Online. ${ }^{19}$

The second variety of interpretation of art rock is defended by the musicologist Allan F. Moore. In his book Rock: The Primary Text he says that the category progressive rock is comprised of a number of music styles or substyles, for instance art rock, hard rock and folk rock. ${ }^{20}$ Katherine Charlton believes that progressive rock is a wider term because besides art rock it includes the style-genre type jazz rock. ${ }^{21}$ The same interpretation is backed by the generally recognized internet server Prog Archives.com. The term progressive rock there covers a much varied style-genre spectrum of rock: art rock, canterbury scene, crossover prog, eclectic prog, experimental/post metal, heavy prog, indo prog/raga rock,

net/genre2.html>; Progbibliography.de [online], available at www: <http://progbibliography.de/>; Patrick T. Will, "Art Rock”, in: Don Michael Randel (ed.), The New Harvard Dictionary of Music (Cambridge, 1996), col. 56; Edward Macan, Rocking the Classics: English Progressive Rock and the Counterculture (New York, 1997), p. 26-27; John Covach, "Progressive Rock, Close to the Edge, and the Boundaries of Style", in: John Covach and Graeme M. Boone (eds.), Understanding Rock: Essays in Musical Analysis (New York, 1997), p. 3; Nors S. Josephson, "Bach Meets Liszt: Traditional Formal Structures and Performance Practices in Progressive Rock", Musical Quarterly, 76 (1992), No. 1, p. 67-92; Bill Martin, Music of Yes: Structure and Vision in Progressive Rock (Chicago, 1996), p. 8 .

17 Brian Robinson, “Somebody Is Digging My Bones”, in: Kevin Holm-Hudson (ed.), Progressive Rock Reconsidered (New York, 2002), p. 235.

18 "Progressive Rock", in: Patricia Romanowski, Holly George-Warren and Jon Pareles (eds.), The New Rolling Stone Encyclopedia of Rock \& Roll (New York, 1995), col. 796.

19 Bernward Halbscheffel, Rockmusik und klassisch-romantische Bildungstradition (Berlin, Freien Universität Berlin, Dissertation, 2000), p. 89; "Art Rock", in: The Oxford Companion to Music and Grove Music Online. The databases are available within the system Oxford Music Online, available at www: <http://www.oxfordmusiconline.com/public/>.

20 Allan F. Moore, Rock: The Primary Text: Developing a Musicology of Rock (Buckingham, 1993), p. 69.

${ }^{21} \quad$ Katherine Charlton, Rock Music Styles: A History (Boston, 2003), p. 217. 
Italian symphonic prog, jazz rock/fusion, kraut rock, neo progressive, post rock/math rock, prog folk, progressive electronic, progressive metal, psychedelic/space rock, RIO/ avant rock, symphonic prog, tech/extreme prog metal, zeuhl, prog related, proto prog. ${ }^{22}$

In some literature, the two terms, art rock - progressive rock, taken as synonymous, and art rock - progressive rock, seen as hierarchically different categories, are combined in various ways. In the music database All Music, art rock/experimental is a superior category which subsumes the style-genre types prog rock/art rock, kraut rock, noise rock, neo prog, canterbury scene and avant prog. ${ }^{23}$

In Anglo-American literature a discussion has been going on for a great many years, on various levels, about the relation between the terms art rock and progressive rock and as to which name is more suitable for such style-genre type of the seventies as the music of the groups Yes and Genesis.

The surviving problems in terminology are partly due to the differences in European and American terminologies in the seventies. In the USA, British art rock groups such as Yes or Genesis were sometimes called progressive rock, whereas by art rock was understood the music represented e.g. by the singer David Bowie and the group Roxy Music. This difference, however, can by no means be generalized because even in that period different views are found among authors of the same provenance.

The American encyclopedia The New Rolling Stone Encyclopedia of Rock \& Roll (1983) has no entry Art Rock, only the entry Progressive Rock. The term is defined as a style of rock music of the seventies in which the principal attributes were the integration of elements of European classical music and instrumental virtuosity. The authors name as principal representatives of progressive rock the British groups Nice, King Crimson, Gentle Giant, Yes, Genesis, Emerson, Lake and Palmer, Van Der Graaf Generator, the Dutch group Focus, and the American group Kansas. The authors admit that this style is often called art rock. They regard this fact as a problem because in their view art rock is often associated with a different rock style, represented for instance by the group Roxy Music, and which otherwise is called glam/glitter rock. They believe that using the term art rock as a synonym to progressive rock can lead to misunderstanding. ${ }^{24}$

The American authors Ed Ward, Geoffrey Stokes and Ken Tucker take an opposite view. In the book Rock of Ages (1986) they call the concrete style-genre type of the rock of the seventies, represented by groups Emerson, Lake and Palmer, Jethro Tull, Yes and Genesis as art rock. The term progressive rock is referred to as a possible terminological alternative but in the book it is not used..$^{25}$

22 Progarchives.com [online], [quoted on 3 Sept. 2007], available at www: <http://www.progarchives. com/>.

23 All Music [online], [quoted on 12 Dec. 2008], available at www: 〈http://www.allmusic.com/>.

24 "Progressive Rock", in: Patricia Romanowski, Holly George-Warren and Jon Pareles (eds.), The New Rolling Stone Encyclopedia of Rock \& Roll (New York, 1995), col. 796.

25 Ed Ward, Geoffrey Stokes and Ken Tucker, Rock of Ages: The Rolling Stone History of Rock and Roll (New York, 1986), p. 480. 
Another American author, Charles Brown, in his book The Art of Rock and Roll (1983) points out the differences between the terms art rock and progressive rock. Both terms, he says, mean almost identical styles, both based on a fusion of rock and European or non-European classical music that too place in the seventies. Brown believes that the difference consists in the fact that progressive rock does not quote from art music. ${ }^{26}$ Some contemporary authors, for instance the American musicologists John Covach, Edward Macan or the British writer Paul Stump, start from the definitions in the generally accepted encyclopedia, The New Rolling Stone Encyclopedia of Rock \& Roll, and tend to call the particular style-genre type of rock music of the seventies progressive rock. And yet they admit the use of the synonymous term art rock, or the terms classical rock and symphonic rock. ${ }^{27}$ On the other hand, the American musicologist Katherine Charlton finds the term art rock as a suitable name for the style-genre type, and so does her British colleague Allan F. Moore. ${ }^{28}$ The majority of major Anglo-American encyclopedias of music focusing on modern popular music, e.g. the British encyclopedia The Penguin Encyclopedia of Popular Music, The Encyclopedia of Popular Music and the American Lillian Roxon's Rock Encyclopedia and The Encyclopedia of Pop, Rock and Soul, use both terms at random, with no clear differentiation between them; the same approach is found in the major German encyclopedia, Rock-Lexikon. ${ }^{29}$

From what was said above it follows that the issue of a uniform terminology for the style-genre type of the seventies is a major problem, not only in the Anglo-American sphere. In Czech literature a similar problem is encountered; the situation there is, however, less ambiguous. Josef Vlček in the encyclopedia Rockové směry a styly writes about the term progressive rock: "One of the most misleading terms in rock music. Used from the second half of the sixties for more ambitious streams in rock music, in the early seventies it referred to the arriving art rock. The name, however, made the listeners disoriented because it raised this style to a rock avant-garde. For this reason this name in the middle of the eighties began to recede from the press even though to this day the American professional literature makes use of the term progressive rock for the first phase of art rock, which was in contrast to the fashionable glitter and hard-rock." ${ }^{30}$ The issue of the relation between art rock and progressive rock was also studied by Petr Dorůžka. In the volume

26 Charles Brown, The Art of Rock and Roll (Englewood Cliffs, N. J., 1983), p. 180.

27 See for instance Edward Macan, Rocking the Classics: English Progressive Rock and the Counterculture (New York, 1997), p. 27; John Covach, "Progressive rock, Close to the Edge, and the Boundaries of Syle", in: John Covach and Graeme M. Boone (eds.), Understanding Rock: Essays in Musical Analysis (New York, 1997), p. 3.

28 See for instance Katherine Charlton, Rock Music Styles: A History (Boston, 2003), p. 217; Allan F. Moore, Rock: The Primary Text: Developing a Musicology of Rock (Buckingham, 1993), p. 69.

29 Donald Clarke (ed.), The Penguin Encyclopedia of Popular Music (London, 1998); Colin Larkin (ed.), The Encyclopedia of Popular Music (Oxford, 2006); Ed Naha and Lillian Roxon (eds.), Lillian Roxon's Rock Encyclopedia (New York, 1978); Irwin Stambler (ed.), The Encyclopedia of Pop, Rock and Soul (New York, 1989); Siegfried Schmidt-Joos (ed.), Rock-Lexikon 1/2 (Reinbek bei Hamburg, 2008).

Josef Vlček, Rockové směry a styly (Prague, 1988), p. 46. 
Po stopách progresivního rocku he writes that the term progressive rock originated in the sixties when it meant a creative approach and not a style of music. By creative approach he means primarily the experimenting in rock, as it in those days turned toward the use of elements of classical music and from which in the seventies the music style art rock developed. By this term Dorůžka understands the music of groups Yes, Genesis and a few more. ${ }^{31}$ Some Czech definitions register other criteria when distinguishing between art rock and progressive rock. A brief and somewhat vague definition of the two terms is found in the general encyclopedia Universum in the entry Art Rock. The style was defined there thus: "[art rock] from the beginning of the seventies a stream of rock music, which aimed at expanding the boundaries of the genre. Inspiration by the great forms of European classical music of the $19^{\text {th }}$ century [...]. Distinguished by musical compositions with large instrumental passages and dramatic changes of tempo and rhythm." Next he writes: "Sometimes also the term progressive rock is used, though a far greater inspiration by modern art than by classical music is found in it." 32

While Anglo-American authors are relatively undecided about which term is more suitable for a particular style-genre type of the seventies, the situation in our country, as it was pointed above, is less ambiguous. Czech literature in most cases preferred the term art rock. The interpretation of the term art rock as a cover term for artistically ambitious style-genre types of the rock, such as jazz rock, kraut rock, avant rock, glam rock, etc., is not common here. There is much evidence for the fact that Czech literature on music associates art rock especially with the music of the groups Yes and Genesis and not with the jazz rock of the Mahavishnu Orchestra, glam rock of David Bowie or the kraut rock of the group Tangerine Dream, etc. For instance the music publicists Ondřej Konrád and Vojtěch Lindaur in their article Umělecký (art)rock [Artistic (Art) Rock] write of the music "compartment" art rock "as it was defined in the world by Yes, Pink Floyd, Genesis, King Crimson but also by Frank Zappa." ${ }^{33}$ In the university textbook Úvod do problematiky hudby jazzového okruhu [Introduction to the Issues of Music in the Sphere of Jazz] the musicologist Ivan Poledñák writes: "Peak representatives of this stream [art rock] were the groups King Crimson, Genesis, Pink Floyd, Yes." ${ }^{34}$ Art rock as a name for a particular style-genre type of the seventies is confirmed by the musicians themselves who had a share in this kind of work. Oldřich Veselý, a member of the Blue Effect group, which is held to be the principal representative of the Czech art rock in the second half of the seventies and which music in this day most approaches the British group Yes, said: "at

31 Petr Dorůžka, "Po stopách progresivního rocku”, in: Petr Dorůžka (ed.), Hudba na pomezí (Prague, 1991), p. 17-28.

32 “Art Rock", in: Josef Čermák (ed.), Universum: všeobecná encyklopedie, část $1 / A-F$ [Universum: General Encyclopedia, Volume 1/A-F] (Prague, 2002), p. 65.

33 Ondřej Konrád and Vojtěch Lindaur, Život v tahu aneb třicet rocků rocku [Life in Tension or Thirty Years of Rock] (Prague,1990), p. 103.

34 Ivan Poledñák, Úvod do problematiky hudby jazzového okruhu [The Introduction into the Issues of Music of the Jazz Field] (Olomouc, 2000), p. 58. 
that time this music was unambiguously called art rock" ${ }^{35}$ The musicologist Petr Dvorník in his diploma thesis (1981) mentions in connection with Czech art rock the work of the group Blue Effect and the groups of the same style, Synkopy and Progres $2 .{ }^{36}$ If today a Czech listener of rock music was asked what he understands by art rock, most probably the answer would be the music of the group Yes in the seventies. In Czech music literature, the term progressive rock is by far not so frequent as the term art rock, which is so much fixed here that the authors mention it in general musicological publications such as Slovník české hudební kultury [Encyclopedia of Czech Music Culture] and it is found even in textbooks of music education. References to progressive rock, prog rock or progresivní rock [progressive rock] are found there seldom. If in our country in connection with art rock the term progressive rock appears, it would mostly be in a wider, historically unbounded sense, and not in a too specific area of music.

Although for Czechs the term art rock is primarily linked with the type of rock music of the seventies, represented by groups Yes or Genesis, there are other terms in circulation as well. In particular the young generation of rock audiences uses the term art rock for the relatively varied area of indie rock. To a wider understanding of the category art rock is also oriented for instance the server Art rock.cz, which concentrates on a wide spectrum of style-genre types of rock music.

In addition to the term progressive rock, art rock may by called by other terms as well. Some of them in a particular phase of the development of rock designated or still designate some partial areas of art rock, these categories may to some degree be taken for the style-genre subtypes of art rock. On the other hand others in some particular cases function as synonymous or alternative terms for art rock. These categories include for example classical rock, baroque rock, symphonic rock, orchestral rock, smart rock, rockaphonic, electronic rock, studio rock, techno rock, flash rock, techno-flash, pomp rock, literary rock, science fiction rock, india rock and several more.

As this study suggests, rock music is a very wide, richly stratified and from the aspect of the style-genre hierarchy a rather complicated area. The wide spectrum of its layers goes from the most general category rock, through the terms of middle generality such as rock and roll, hard rock, jazz rock and heavy metal, to the terms with a relatively narrow definition, for instance west coast rock, southern rock, canterbury scene, Detroid sound, pub rock, raga rock, etc. These terms arise spontaneously during the long development of the music type and are often ambiguous. Their defining and hierarchization, which are prerequisites to an objective description of modern popular music in the written history of music, are thus a fairly difficult task.

As I said in the introduction, due to the vast extent of modern popular music, all semantic modifications and deviations of particular terms cannot be established but with a due distance of time lag, at least their basic semantic variants can be defined as they

35 Czech Television Series Bigbit, part 24.

36 Petr Dvorník, Nové prvky v naší nonartificiální hudbě [New Elements in Our Popular Music] (Brno, Faculty of Philosophy of the University of J. E. Purkyně in Brno, Theses, 1981), p. 74-127. 
became fixed in the wide social consciousness. And that was the objective of this study focused on the term art rock.

Translated by Jaroslav Peprník

\title{
Art-Rock: Begriffsbestimmung mit Berücksichtigung der Entwicklung der tschechischen Bezeichnungspraxis
}

\begin{abstract}
Zusammenfassung
Mit Hilfe einer Analyse der relevanten Literatur und weiterer Informationsquellen wird in dem Text die Entwicklung des Begriffs Art-Rock im angloamerikanischen und im tschechischen Kulturkontext seit der Zeit seines Entstehens in der ersten Hälfte der siebziger Jahre des zwanzigsten Jahrhunderts bis heute erfasst. In erster Linie wird das Augenmerk auf die Bedeutungswandlungen und Modifikationen des Begriffs im Laufe von mehreren Jahrzehnten gelegt. Ferner werden hier auch die Möglichkeiten der Verwendung des Terminus Art-Rock im Rahmen der gegenwärtigen Kommunikation über die Rock-Musik betrachtet. Der Text reflektiert auch auf eine bedeutende Art und Weise die Problematik von verwandten Begriffen, Synonymen und alternativen, mit dem Terminus Art-Rock verbundenen Bezeichnungen, deren Existenz die Kommunikation über die hier besprochene Musikgattung oft schwierig macht. In diesem Sinne wird speziell der Zusammenhang zwischen den Begriffen Art-Rock und Progressiv-Rock betont. Ein wichtiger Bestandteil der Studie stellt auch ein Vergleich des weltweiten, respektive angloamerikanischen Usus in der Bezeichnung der modernen Pop-Musik mit der Entwicklung der tschechischen Praxis in diesem Bereich dar.
\end{abstract}

Art rock: vymezení pojmu s přihlédnutím k vývoji české označovací praxe

Shrnutí

Prostřednictvím analýzy relevantní literatury a dalších informačních zdrojů text zachycuje vývoj pojmu art rock v angloamerickém a českém kulturním kontextu od doby jeho vzniku v první polovině sedmdesátých let dvacátého století do současnosti. Pozornost je věnována $v$ prvé řadě významovým proměnám a modifikacím pojmu v průběhu několika desítek let, dále rovněž možnostem používání termínu art rock v rámci současné komunikace o rockové hudbě. Text také významným způsobem reflektuje problematiku př́buzných pojmů, synonymních výrazů a alternativních označení spjatých s termínem art rock, jejichž existence často znesnadňuje komunikaci o pojednávaném hudebním typu. 
V tomto smyslu je největši důraz položen na vztah pojmů art rock a progressive rock. Důležitou součástí studie je komparace světového, respektive angloamerického označovacího úzu moderní populární hudby s vývojem české označovací praxe.

\section{Keywords}

Modern popular music; rock; art rock; progressive rock; terminology; designating practice; Czech designating practice. 